\title{
Green Synthesis of CuO Nanoparticles Using Leaf Extract of Catha edulis and Its Antibacterial Activity
}

\author{
Kiflom Gebremedhn ${ }^{1,2}$, Mebrahtu Hagos Kahsay ${ }^{1}$ and Muluken Aklilu ${ }^{2}$ \\ 1. Chemistry Department, Faculty of Natural and Computational Sciences, Woldia University, P.O. BOX 400, Woldia, Ethiopia \\ 2. Chemistry Department, College of Science, Bahir Dar University, P.O. BOX 2145, Bahir Dar, Ethiopia
}

\section{Graphical Abstract}

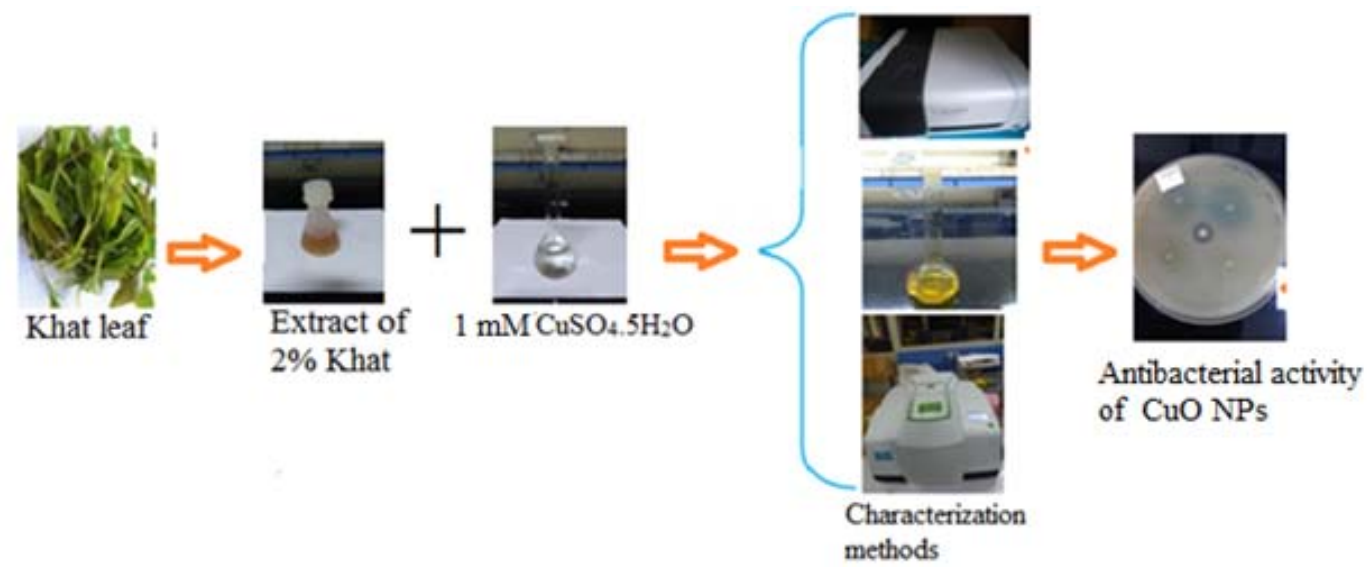

\begin{abstract}
Copper oxide nanoparticles (CuO NPs) have attracted huge attention due to catalytic, electric, optical, photonic, and antibacterial activity. The use of plant leaf extracts in the biosynthesis of nanostructured materials is an eco-friendly, non-toxic and cost effective approach. Hence, this study aims to provide an updated survey of the main green synthesis method of CuO NPs using leaf extract of Khat, its characterization and studies on antibacterial activities. The synthesis of CuO NPs was done by reducing $1 \mathrm{mM}$ $\mathrm{CuSO}_{4} \cdot 5 \mathrm{H}_{2} \mathrm{O}$ with $2 \%(\mathrm{~m} / \mathrm{v})$ aqueous leaf extract of Khat under optimum conditions $(\mathrm{pH}=11)$. The formation of CuO NPs has been confirmed first by the color change from colorless to light green and then to greenish yellow. The kinetics of the reaction was studied using UV-Visible (UV-Vis) spectrophotometer that showed surface plasmon resonance at $333 \mathrm{~nm}$. The CuO NPs exhibit antimicrobial activity against two human pathogens viz. Salmonella typhimurium and Escherichia coli with an average zone of inhibition of $12.5 \mathrm{~mm}$ and $8 \mathrm{~mm}$, respectively. Therefore, the current study reveals a convenient utilization of Catha edulis extract as a reducing agent for the successful synthesis of CuO NPs through a green synthesis method to obtain significantly active antibacterial material.
\end{abstract}

Key words: CuO NPs, Catha edulis Forsk, green synthesis, FT-IR, UV-Vis, antimicrobial activity.

\section{Introduction}

The term "Nano" comes from the Greek word dwarf which reveals the particle size to lie in the range of 1 to $100 \mathrm{~nm}$. Theoretical definition of nanotechnology was started with a speech delivered by Richard Feynman in

Corresponding author: M.H., Kahsay, Ph.D., assistant professor, research field: materials science. Email: hagosmebrahtu@gmail.com.
1959. He was able to lecture the title "There's Plenty of Room at the Bottom”, explaining the chance to express things at atomic level $[1,2]$. Nanoparticles possess unique physico-chemical, optical and biological properties which can be manipulated suitably for desired applications [3]. This is due to its quantum size effect and large surface area to volume ratio [3, 4].

Nanoparticles have been at large used in electronics, optoelectronic, magnetic, information storage, 
recording media, sensing devices, catalysis, chemistry, environment, energy, agriculture, medicine and drug delivery, communication technology, aircraft technology, heavy industry and consumer goods etc. [5, 6]. Copper is highly conductive but significantly cheaper than gold $(\mathrm{Au})$ and silver (Ag) where early studies have been focusing on. Most copper nanoparticles (Cu NPs) synthesized so far have surface oxide layers because the $\mathrm{CuO}$ phases are thermodynamically more stable than pure copper [6]. $\mathrm{CuO}$ nanostructure has monoclinic structure and is a p-type semiconductor with a narrow band gap of 1.21-2.51 eV [7]. $\mathrm{CuO}$ is also a high dielectric constant semiconductor [8].

$\mathrm{CuO}$ NPs are applied in areas such as biocidal activity, antioxidant, antibacterial, magnetic phase transitions, gas sensors, catalysis, and superconductivity [7, 9-12]. In addition, it has been reported that adding $4 \%$ of $\mathrm{CuO}$ improves the thermal conductivity of water by $20 \%$ [13]. The properties of the CuO NPs depend on the synthesis method selected which again impacts their applications. The most important features are size and morphologies of the nanoparticles which are believed to directly affect their properties [14, 15].

The conventional methods employed for the synthesis of nanoparticles can be categorized mainly under physical, chemical and green methods. Almost all of the chemical methods employ expensive, toxic chemicals and energy intensive routes which make them eco-hazardous. They also involve danger by products, concentrated reducing agents, high level of radiation, and contamination from precursor chemicals. This may pose potential environmental and biological risks in a broader sense [1, 4, 6, 11]. As a result the interest in this field has shifted toward "green chemistry" and bio-processor approach. Green chemistry is the design of chemical products and processes to minimize or to eliminate the use and generation of hazardous substances and was developed in principles to guide the chemists in their search towards greenness. Hence, it has now opened up a new era of safe nanotechnology [16, 17].

In green methods, extract of living organisms such as plants, microorganisms and enzymes etc. are used [4]. However, the exact mechanism for the synthesis of nanoparticles using biological agents has not been devised yet. But it is believed that different biomolecules are responsible for the synthesis of nanoparticles [18]. Plants possess components that can act as reducing, capping, chelating agent and stabilizers for nanoparticles production. Noble metals nanoparticles of high reduction potentials have been successfully synthesized [19].

In recent years, green synthesis of metal nanoparticles using biomolecules present in plant extracts such as enzymes, proteins, amino acids, vitamins, polysaccharides, saponins and aromatic compounds has been widely dealt. The polyol and the water soluble heterocyclic phytochemical components; flavones, organic acids and quinones are suspected to be responsible for immediate reducing as well as stabilizing agent for the synthesized nanoparticles [20].

The research in the field of biosynthesis has been mainly focusing on Ag and Au NPs, and there have been very few reports on the synthesis of $\mathrm{Cu} / \mathrm{CuO}$ NPs. Till August 2014, the research in the field of biosynthesis mainly focused on synthesis of Ag NPs (7,699 papers, 59\%), Au NPs, ZnO NPs (4,640 papers, $36 \%$ ) and finally $\mathrm{Cu} / \mathrm{CuO}$ NPs (690 papers, 5\%) according to Ref. [21].

On the other hand green synthesis of CuO NPs by using various plant part extracts has been reported such as: Acalypha indica [22], Phyllanthus Amarus Leaf [23], T. arjuna bark extract [24], Calotropis gigantean leaf extract [25], Malva sylvestris leaf extract [26], aqueous extract of flowers of Cassia alata [27], Gloriosa superba L. [28], Carica papaya [29] etc.

Having a look at the reports above, compared to other metal nanoparticles such as Ag NPs, Au NPs, Zn NPs etc., CuO NPs have been green synthesized less. Hence, green synthesizing more $\mathrm{CuO}$ NPs makes the 
$\mathrm{CuO}$ NPs to be cheaply available so as to be used in different fields of applications. One way of doing this is using more local and easily available plants. Therefore, Catha edulis Forsk (Khat) has been selected for such a purpose.

As of our knowledge, no literature so far has reported the synthesis of $\mathrm{CuO}$ NPs using leaf extract of Catha edulis Forsk. The researchers believe that this work is the first to report the synthesis of CuO NPs using leaf extract of Catha edulis Forsk.

Catha edulis Forsk is an evergreen plant grown by grafting which is cultivated as a bush or small tree. It is mainly found in Ethiopia, Yemen, Somali, Sudan, Madagascar and South Africa. It grows at altitudes of 1,500-2,500 meters with a height of 3-8 meters. It needs about 10 years for attaining maturity. But the leaves and shoots can be harvested after 3-4 years. Khat is harvested throughout the year. Present-day classification places the genus Catha in the family Celastraceae and recognizes but one species, Catha edulis, as cited in Ref. [30].

In Ethiopia depending upon geographical location, various chemotypes of Khat are cultivated and these chemotypes differ in color, height and size of the young shoots of the leaves and the plant as a whole. They are sold under the designation names of their corresponding growing areas, e.g., "Wondo Chat” from Wondo, "Gelemso" and "Aweday Chat" from Harar, "Bahir Dar Chat” from Bahir Dar, "Sebeta Chat” from Sebeta etc. [31]. Khat, for many years has been chewed by people around different parts of the world for its stimulating activity.

The phytochemicals found in Khat include: alkaloids, terpenoids, flavonoids, sterols, glycosides, tannins, amino acids, vitamins and minerals [32, 33]. The alkaloids, cathinone, are presumably the main psychoactive component of Khat [34]. Therefore, Khat has been selected as a good choice for this work.

From the many Khat types cultivated in Ethiopia, “Abay Dar chat" from Bahir Dar, Ethiopia was selected and collected for this study. It is known for its high stimulating activity.

Nanoparticles are now being increasingly utilized for their medical applications and are used as an alternative approach to control infectious agents. The bactericidal effect of metal nanoparticles has been attributed to their small size and high surface area to volume ratio, which enables them to interact closely with microbial membranes [10].

Hence, the main objective of this study is to synthesize $\mathrm{CuO}$ NPs using leaf extract of Khat and assessing its antibacterial activity against a sample of bacteria.

\section{Materials and Methods}

\subsection{Materials}

All chemicals were analytical grade and were used without further purification. Copper(II) sulphate pentahydrated $\left(\mathrm{CuSO}_{4} \cdot 5 \mathrm{H}_{2} \mathrm{O}, 98.5 \%\right)$, ferric chloride $\left(\mathrm{FeCl}_{3}, 99 \%\right)$, hydrochloric acid $(\mathrm{HCl}, 35.4 \%)$, and sulphuric acid $\left(\mathrm{H}_{2} \mathrm{SO}_{4}, 98 \%\right)$ were from Loba Chemie Pvt. Ltd, India; ethanol $\left(\mathrm{C}_{2} \mathrm{H}_{5} \mathrm{OH}, 99.5 \%\right)$ was from UNI-CHEM Chemical Reagents; Methanol and Gentamicine were from Abcek adtek (P) Ltd; potassium chloride (KBr) was from Uvasol, Germany; agar Hilten Muller was from Oxoid CM, UK; chloroform (99.9\%) was from Fisher Scientific UK Limited, UK; sodium hydroxide $(\mathrm{NaOH}, 98 \%)$ and ammonia solution (25\%) were from Blulux Laboratories (P) Ltd; Benedict's solution, magnesuim chloride $\left(\mathrm{MgCl}_{2}, 98 \%\right)$, iodine solution (80\%), potassium Iodide (KI, 99\%) were from Abron Chemicals, India. UV-Vis spectrometer (Aglient technologies, Cary 60 UV-Vis) and FT-IR (Perkin Elmer) were also used. All the glasswares were washed with distilled water and dried in oven. De-ionized water was used in all of the experimental works.

\subsection{Preparation of Leaf Extract of Catha edulis}

Fresh green plants of Khat were collected from one of the local Khat shops at Bahir Dar city, Ethiopia and it is known as "Abay Dar Chat" by the local people 
from that area, in Fig. 1. The Khat leaf was collected and used at the months of March and May. The leaves were thoroughly washed and rinsed with distilled water, and then finely cut. The leaves were then homogenized using mortar and pestle. The extraction was carried out by mixing $2 \mathrm{~g}$ of the grinded Khat with $100 \mathrm{~mL}$ of de-ionized water and was immediately stirred using magnetic stirrer for 2 to $3 \mathrm{~min}$. It was then heated for about two minutes at a temperature of $50-60{ }^{\circ} \mathrm{C}$. After wards, it was allowed to cool down to room temperature. The mixture was, firstly, filtered using Abron Qualitative filter paper and then using Quantitative filter paper, after which the collected filtrate was kept at $4{ }^{\circ} \mathrm{C}$ for further synthesis of $\mathrm{CuO}$ NPs [7].

\subsection{Qualitative Phytochemical Screening of Leaf} Extract of Catha edulis

\subsubsection{Test for Alkaloids (Wagner's Test:} Iodine-Potassium Iodide Solution)

One point two (1.2) g of iodine and $2 \mathrm{~mL}$ of $\mathrm{H}_{2} \mathrm{SO}_{4}$ were mixed and diluted to $100 \mathrm{~mL}$ solution. Ten (10) $\mathrm{mL}$ of the alcoholic extract was acidified by adding $1.5 \%$ $(\mathrm{v} / \mathrm{v})$ of $\mathrm{HCl}$ and then few drops of Wagner's reagent were added. Formation of yellow or brown precipitate was assessed to confirm the presence of alkaloids.

\subsubsection{Test for Glycosides}

A small amount of alcoholic extract was dissolved in $1 \mathrm{~mL}$ of distilled water and aqueous $\mathrm{NaOH}$ solution was dissolved in $1 \mathrm{~mL}$ of distilled water and then it was added to the extract. Formation of reddish brown color was taken as an indicator for the presence of glycosides.

\subsubsection{Test for Tannins (Ferric Chloride Test)}

One (1.0) mL extract was stirred with $1.0 \mathrm{~mL} \mathrm{FeCl}_{3}$ solution; the occurrence of a greenish black precipitate indicated the presence of tannins.

\subsubsection{Test for Flavonoids}

Zero point two (0.2) $\mathrm{mL}$ extract was added to $2 \mathrm{~mL}$ $10 \%(\mathrm{~m} / \mathrm{v}) \mathrm{FeCl}_{3}$ solution and the mixture was shaken. A wooly brownish precipitate indicated the presence of flavonoid.

\subsubsection{Test for Saponins}

Zero point two (0.2) $\mathrm{mL}$ extract was mixed with 5.0 $\mathrm{mL}$ distilled water, shaken for $20 \mathrm{~min}$ and the persistence of foams indicated the presence of saponins.

\subsubsection{Test for Steroids (Salkowski Test)}

Two (2) $\mathrm{mL}$ of chloroform extract and $1 \mathrm{ml}$ of concentrated $\mathrm{H}_{2} \mathrm{SO}_{4}$ acid were added carefully along sides of the test tubes. The mixture was then examined to reveal a red color in the chloroform layer which confirms the presence of steroids.

\subsubsection{Test for Phenols}

The Khat extract was treated with 3-4 drops of $\mathrm{FeCl}_{3}$ solution. It was then left to form bluish black color that indicates the presence of phenols.

2.3.8 Test for Carbohydrates (Benedict Test and Iodine Test)

Few drops of Benedict solution were added into the

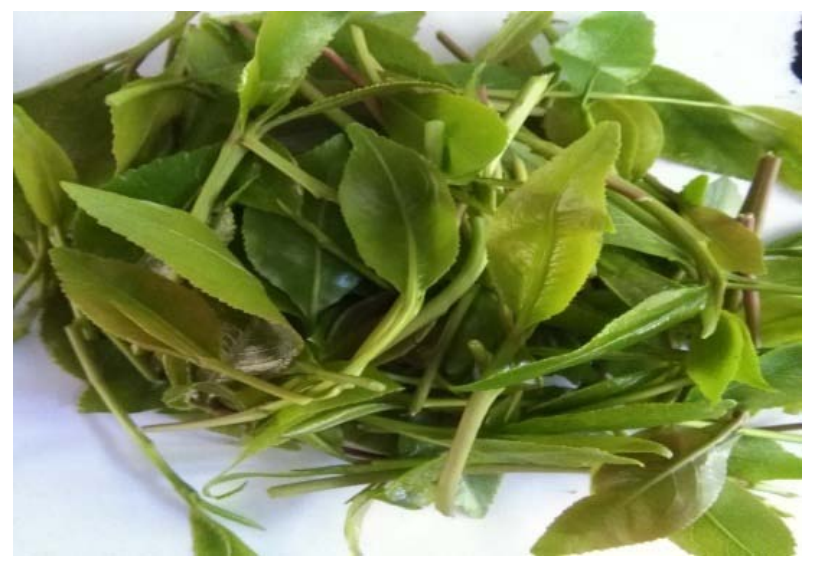

Fig. 1 Fresh leaves of “Abay Dar Chat”. 
plant extract and it was checked for its formation of brick red color which is used to confirm the presence of glucose and few drops of iodine were added in other extract where a dark blue color formation confirmed the presence of starch [35].

\subsection{Synthesis of Copper Oxide Nanoparticles}

In a typical reaction mixture, $45 \mathrm{~mL}$ of aqueous 1 $\mathrm{mM} \mathrm{CuSO}{ }_{4} \cdot 5 \mathrm{H}_{2} \mathrm{O}$ solution was treated with $2 \mathrm{~mL} 2 \%$ $(\mathrm{m} / \mathrm{v})$ leaf extract of Khat and stirred magnetically at room temperature; until the light blue color was changed to light green. Then the mixture was heated at $50-60{ }^{\circ} \mathrm{C}$ for 6 min. Following, it was allowed to cool down. Afterwards, the mixture was treated with $1 \mathrm{M}$ $\mathrm{NaOH}$ solution drop by drop for a specific $\mathrm{pH}=11$. The synthesized $\mathrm{CuO}$ NPs were characterized using the visual observation, the UV-Vis and FT-IR spectroscopies [3]. Finally, the CuO NPs formed was examined for its antibacterial activity.

\subsection{Characterization of Copper Oxide Nanoparticles}

The synthesized $\mathrm{CuO}$ NPs were characterized by visual observation, UV-Vis absorption spectroscopy and Fourier Transform Infrared spectroscopy. During synthesis of the nanoparticles, every color change for every step was noticed carefully. The next characterization method employed was the UV-Vis spectroscopy. To do this, samples of the mixture were collected periodically to monitor the completion of bio-reduction of $\mathrm{Cu}^{2+}$ ions in aqueous solution and subsequently analyzed in UV-Vis spectra between wavelengths 200 to $700 \mathrm{~nm}$ with a resolution of $1 \mathrm{~nm}$. The UV-Vis spectrums were recorded and analyzed [3].

FT-IR spectroscopy was used to identify the phytochemicals used to reduce CuO NPs and formation of CuO NPs. Firstly, a drop of the Khat extract was mixed with the $\mathrm{KBr}$ powder so as to form a paste. Afterwards, the paste was taken into the FT-IR and got scanned at a resolution of $8 \mathrm{~nm}$ in a wavenumber range of 400 to $4,500 \mathrm{~cm}^{-1}$. The same procedure was followed to characterize $\mathrm{CuO}$ NPs.

\subsection{Antibacterial Activity of $\mathrm{CuO}$ NPs Using Disc Diffusion Method}

The discs were soaked with double distilled water, $2 \%(\mathrm{~m} / \mathrm{v})$ leaf extract of Khat, $1 \mathrm{mM} \mathrm{CuSO}{ }_{4} \cdot 5 \mathrm{H}_{2} \mathrm{O}$ solution and solution containing $\mathrm{CuO}$ NPs of each type separately. Gentamicin was placed at the center of the plates, used as a positive control. Then, the discs were air dried in sterile condition. The plates containing nutrient agar media were prepared by swabbing them with the microbial cultures (Salmonella typhimurium and Escherichia coli). Previously prepared discs were placed on each part of the plate. The discs were placed in the following order: disc soaked with double distilled water as negative control, disc soaked with solution containing leaf mediated $\mathrm{CuO}$ NPs, disc soaked with leaf extract of Khat, and disc soaked with 1 $\mathrm{mM} \mathrm{CuSO}{ }_{4} \cdot 5 \mathrm{H}_{2} \mathrm{O}$ solution. The plates were incubated at $37^{\circ} \mathrm{C}$ for $24 \mathrm{hr}$. Finally, the maximum zone of inhibition was observed and measured in duplicate against each type of test microorganism [3].

\section{Results and Discussion}

\subsection{Phytochemical Test}

In this study, Khat has been extracted and then the presence of its phytochemicals, such as flavonoids, polyphenols, carbohydrate etc. was checked. Based on the results the naturally existing phytochemicals in the leaf extract were used as a reducing and capping agent during $\mathrm{CuO}$ NPs synthesis. The results of qualitative phytochemical analysis of the Khat extract are shown in Fig. 2, which revealed the presence of secondary metabolites such as phenols, flavonoids, carbohydrates, tannis, alkaloids, etc. Therefore, the Khat extract is composed of phytochemicals which are capable of reducing the $\mathrm{Cu}^{2+}$ ion by donating electrons, capping and stabilizing the formed nanoparticles [36]. For instance, the polyphenolic compounds are very important plant constituents because of the scavenging 


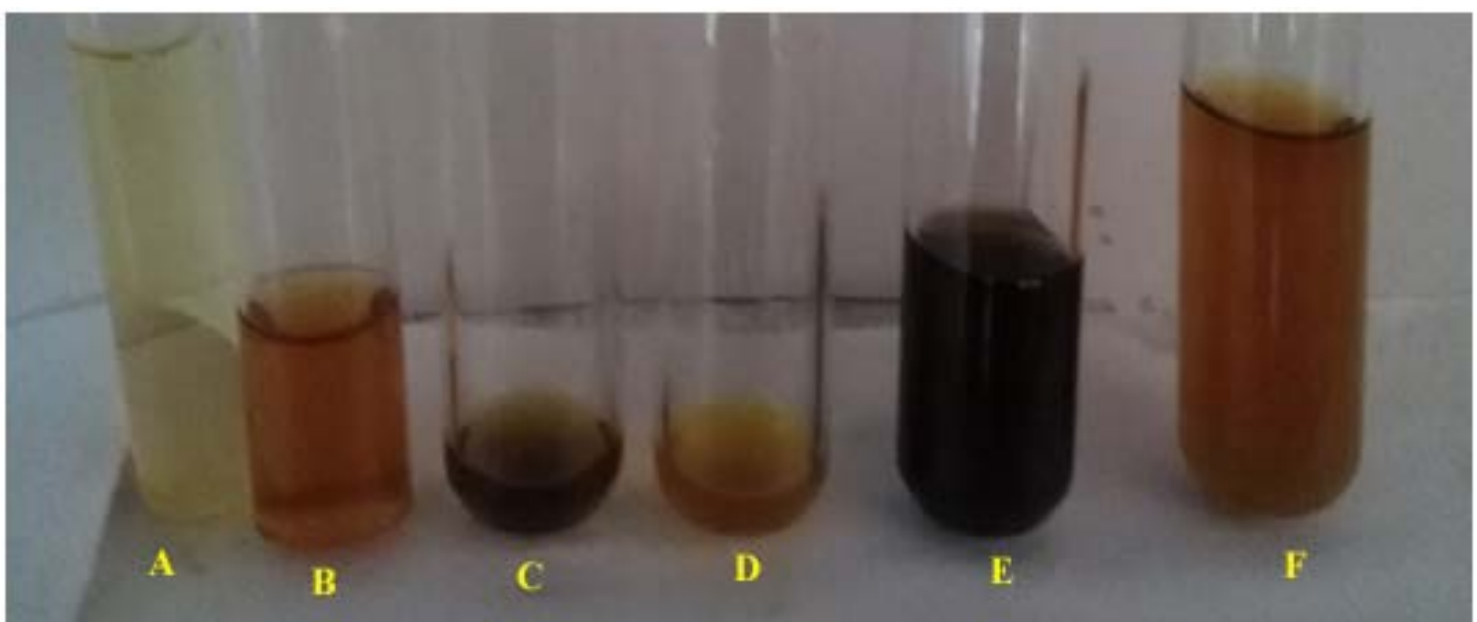

Fig. 2 The color change observed when the leaf extract of Khat was tested for the presence of (A) Alkaloids, (B) Glycosides, (C) Tannins, (D) Flavonoids, (E) Polyphenols and (F) Carbohydrate.

ability of their $-\mathrm{OH}$ groups. It was also reported that the antioxidant property of polyphenolic compounds is mainly due to its redox property which allows them to act as reducing agent [16].

The color changes are indicators of formation of different complexes as a result of oxidation and reduction reactions. For instance, the yellow color for alkaloids indicates that the nitrogen or oxygen atoms of the amide groups of the alkaloids involve in a reaction. In most of the ferric chloride tests, the iron (III) ion forms complexes having different colors depending on the nature of the complexes [36].

\subsection{Characterization of $\mathrm{CuO}$ NPs}

The formation of $\mathrm{CuO}$ NPs was confirmed primarily based on change in color of the reaction mixture. Due to lack of access to microscopic instruments, only direct observation and the spectroscopic instruments i.e., UV-Vis and FT-IR were used to characterize the as synthesized $\mathrm{CuO}$ NPs.

\subsection{Visual Observation}

Formation of $\mathrm{CuO}$ NPs was easily discernible due to changes in color of the solution. The color changes arise due to excitation of surface plasmon resonance in the metal nanoparticles indicating the formation of $\mathrm{CuO}$ NPs. The colorless $1 \mathrm{mM} \mathrm{CuSO} \cdot 5 \mathrm{H}_{2} \mathrm{O}$ solution started changing its color to light green as soon as the leaf extract of Khat was added to it. At the time when the $\mathrm{NaOH}$ solution came in contact with the solution, the light green mixture was spontaneously changed to yellowish green (Fig. 3), indicating the formation of $\mathrm{CuO}$ NPs. In contrast, the color of control solutions i.e., the leaf extract of Khat and $\mathrm{CuSO}_{4} \cdot 5 \mathrm{H}_{2} \mathrm{O}$ solution remained unchanged.

\subsection{UV-Vis Analysis}

The position, shape and intensity of the surface plasmon resonance strongly depend on various factors including the size, shape and monodispersity of the nanoparticles when plasmons interact with the visible light. Therefore, the effect of different factors on the size, shape and monodispersity of the nanoparticles should be observed to design a suitable formulation for production of nanoparticles [37].

The UV-Vis spectra result revealed a strong absorbance at $333 \mathrm{~nm}$ suggesting the formation of $\mathrm{CuO}$ NPs (Fig. 4), while the pure leaf extract of Khat has shown a strong absorbance at $294 \mathrm{~nm}$. This result definitely agrees with the range of $\lambda_{\max }$ values of the $\mathrm{CuO}$ NPs, 250-395 nm at different previous works using plant extracts other than Khat [5, 10, 26, 29, 35].

This shows that during the formation of the $\mathrm{CuO}$ NPs, there is a red shift in wavelength which can be 


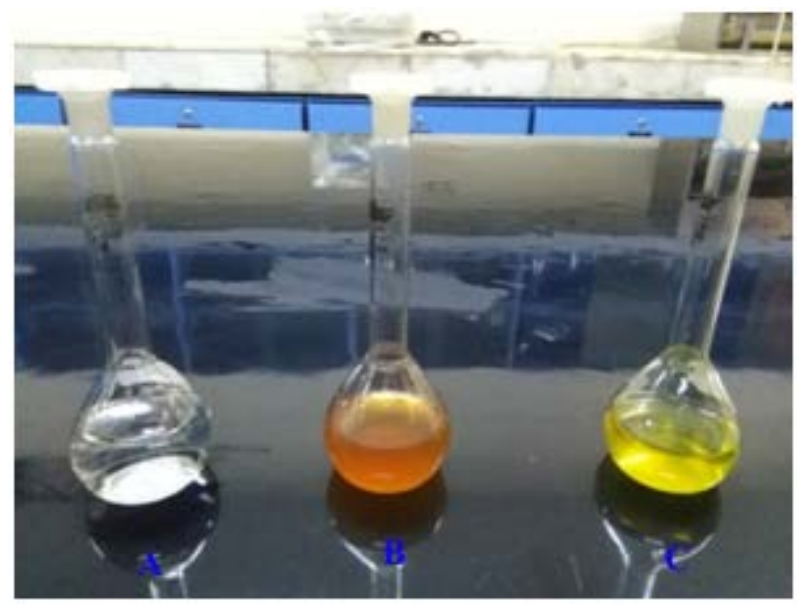

Fig. 3 Color changes observed before and after the formation of $\mathrm{CuO} \mathrm{NPs} \mathrm{(A)} \mathrm{CuSO}_{4} \cdot 5 \mathrm{H}_{2} \mathrm{O}$ precursor, (B) leaf extract of Khat, and (C) CuO NPs.

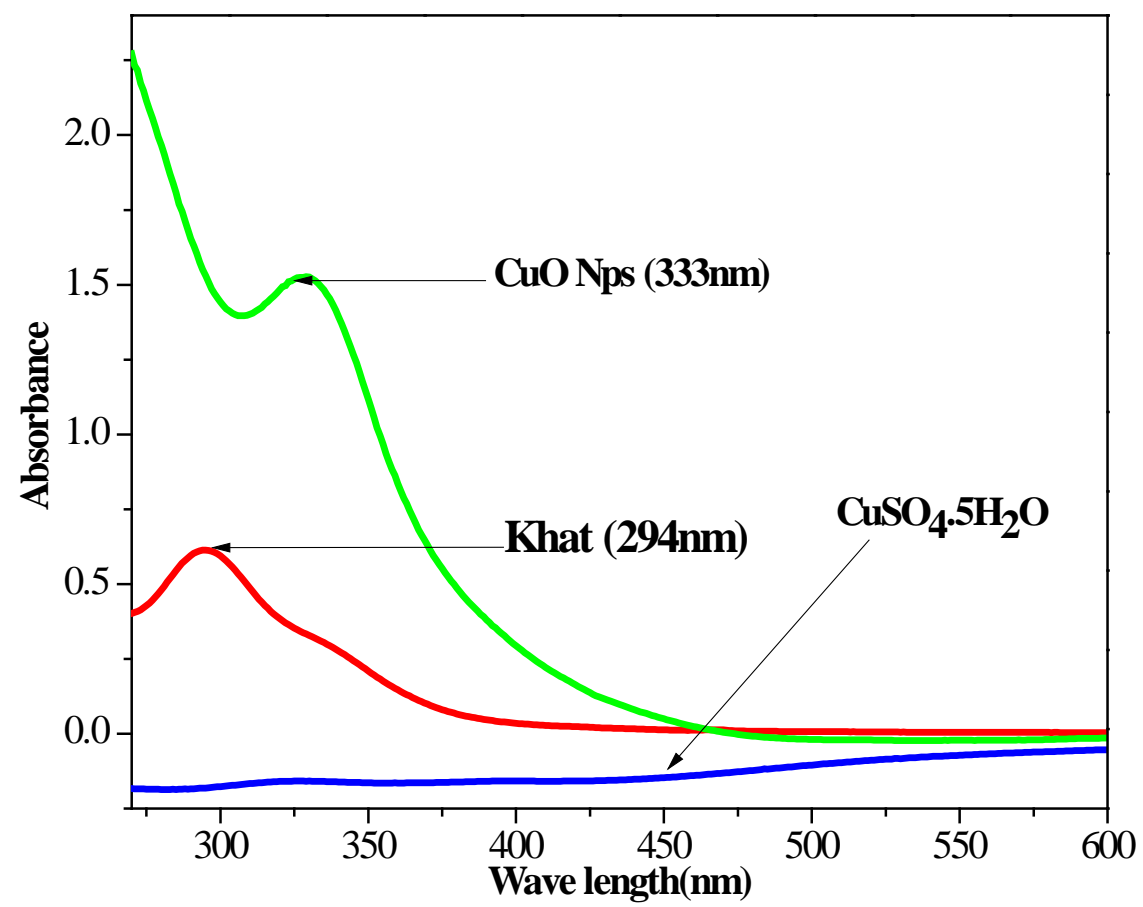

Fig. 4 UV-Vis spectra of $\mathrm{CuSO}_{4} \cdot 5 \mathrm{H}_{2} \mathrm{O}$ precursor (Blue), leaf extract of Khat (Red) and CuO NPs (Green).

considered as an indicator of a newly formed shape and size of particles with different surface plasmon resonance. The peak obtained in this work is even sharper and more intense than some other works on the green synthesis of CuO NPs. This is expected to be the effect of the smaller size of the as synthesized $\mathrm{CuO}$ NPs [37]. Therefore, the color changes and the UV-Vis values are taken as confirmatory results for the formation of the $\mathrm{CuO}$ NPs.

Here parameters were optimized so as to select the best conditions used for the effective synthesis of the $\mathrm{CuO}$ NPs. The parameters were the concentration of both Khat extract and the precursor, as well as $\mathrm{pH}$ of the mixture.

\subsubsection{Optimization of Precursor Concentration}

To optimize the concentration of the precursor two stages were taken. The first stage was at the time when pH was not adjusted. Here the peaks for the CuO NPs were all closer to the peak of the pure Khat extract (294 $\mathrm{nm}$ ) as can be seen in Fig. 5. But they also show small 


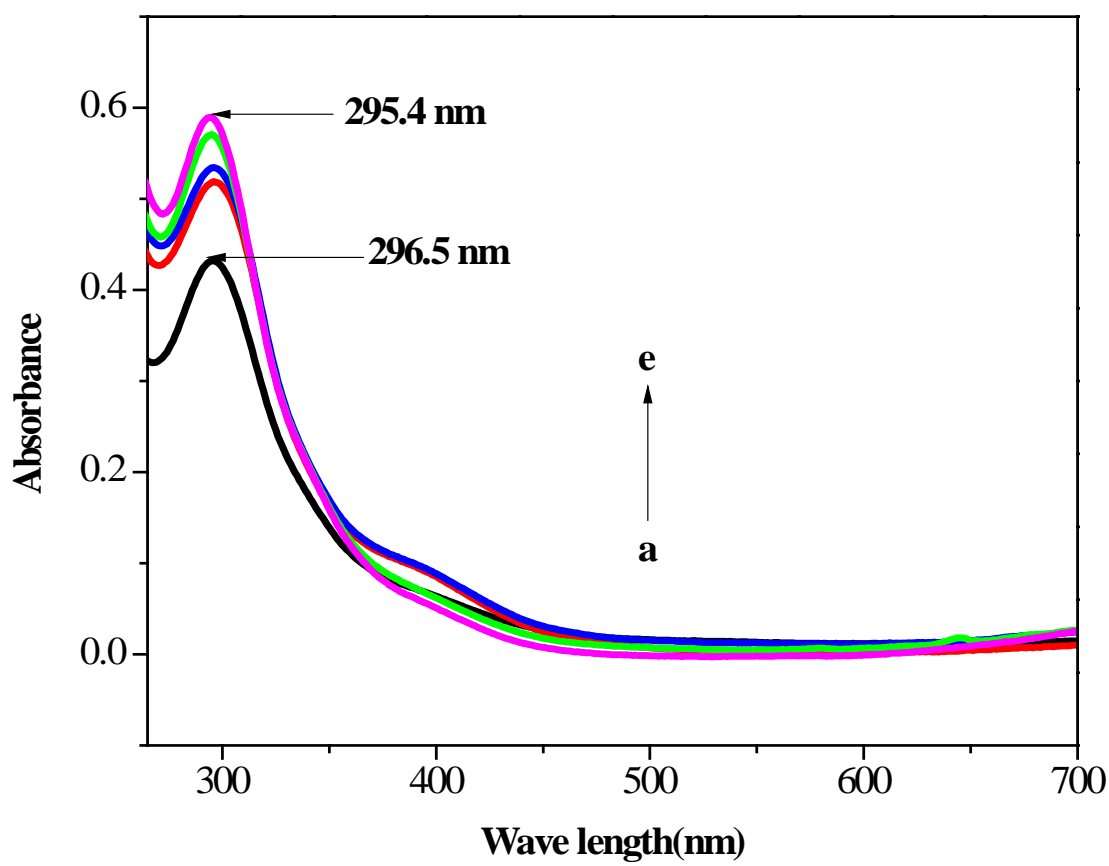

Fig. 5 The UV-Vis spectra of CuO NPs formed using $2 \mathrm{~mL}$ of $2 \%(\mathrm{~m} / \mathrm{v})$ leaf extract of Khat and $45 \mathrm{~mL} \mathrm{of} \mathrm{(a)} 1 \mathrm{mM}$, (b) $2 \mathrm{mM}$, (c) $3 \mathrm{mM}$, (d) $4 \mathrm{mM}$ and (e) $5 \mathrm{mM} \mathrm{CuSO} \cdot \cdot 5 \mathrm{H}_{2} \mathrm{O}$ before $\mathrm{pH}$ was adjusted.

red shift in wavelength where the maximum $\lambda_{\max }$ was obtained at $296.5 \mathrm{~nm}$ when $1-3 \mathrm{mM} \mathrm{CuSO}{ }_{4} \cdot 5 \mathrm{H}_{2} \mathrm{O}$ solutions were used. On the other hand, $4 \mathrm{mM}$ and 5 $\mathrm{mM} \mathrm{CuSO}{ }_{4} \cdot 5 \mathrm{H}_{2} \mathrm{O}$ solutions have shown peaks very much closer to the pure Khat extrat (295.4 nm). It was then easy to conclude that the nanoparticle was not fully formed yet. According to different previously done studies on the synthesis of CuO NPs, there was a need to change the media to basic condition by adding $\mathrm{NaOH}$ solution so as to adjust the $\mathrm{pH}$ [26].

Hence, adding $\mathrm{NaOH}$ solution with the recommended $\mathrm{pH}=10$ (before optimization) was taken as the next step. As soon as it was added, remarkable change in the position of the peaks was observed. All of the peaks have shown more shift in position. Comparing the peaks obtained, it was founded that $1 \mathrm{mM} \mathrm{CuSO} \cdot 5 \mathrm{H}_{2} \mathrm{O}$ was the best concentration of the precursor to be used for the synthesis of the CuO NPs with an intense peak and more red shift as compared to the $2 \mathrm{mM}, 3 \mathrm{mM}, 4 \mathrm{mM}$ and $5 \mathrm{mM} \mathrm{CuSO}_{4} \cdot 5 \mathrm{H}_{2} \mathrm{O}$, as can be seen in Fig. 6. This result definitely agrees with the concentration of $\mathrm{CuSO}_{4}$ used for the synthesis of $\mathrm{CuO}$ NPs using aqueous extract of flowers of Cassia alata [27]. For the $2 \mathrm{mM}$ and $3 \mathrm{mM} \mathrm{CuSO} \cdot 5 \mathrm{H}_{2} \mathrm{O}$, the peaks became broader due to the increase in number of the copper ions to be reduced and form particles of lager size [5]. But for the $4 \mathrm{mM}$ and $5 \mathrm{mM} \mathrm{CuSO}{ }_{4} \cdot 5 \mathrm{H}_{2} \mathrm{O}$ pale blue colour was observed. The color was different from greenish yellow colors of the $\mathrm{CuO}$ NPs formed from 1-3 $\mathrm{mM} \mathrm{CuSO}_{4} \cdot 5 \mathrm{H}_{2} \mathrm{O}$ precursor. This shows that when the concentration of the copper ions in the solution was increased, it has exceeded the amount of reducing agent phytochemicals of the Khat extract. It can even form a respective hydroxide solution. This is expected to happen when the added $\mathrm{NaOH}$ solution does react directly with the copper ions and form $\mathrm{Cu}(\mathrm{OH})_{2}$ with a pale blue colored water insoluble precipitate [38]. This might be the reason why the peaks have shown different trends from that of $\mathrm{CuO}$ NPs synthesized using $1 \mathrm{mM}, 2 \mathrm{mM}$, and $3 \mathrm{mM} \mathrm{CuSO}_{4} \cdot 5 \mathrm{H}_{2} \mathrm{O}$.

3.4.2 Optimization of Concentration of Leaf Extract of Khat

The concentrations of Khat extracts which gave intense peaks were 3, 4, 5 and $6 \%(\mathrm{~m} / \mathrm{v})$ relative to the $1 \%$ and $2 \%$, in Fig. 7. However, it was observed that the 


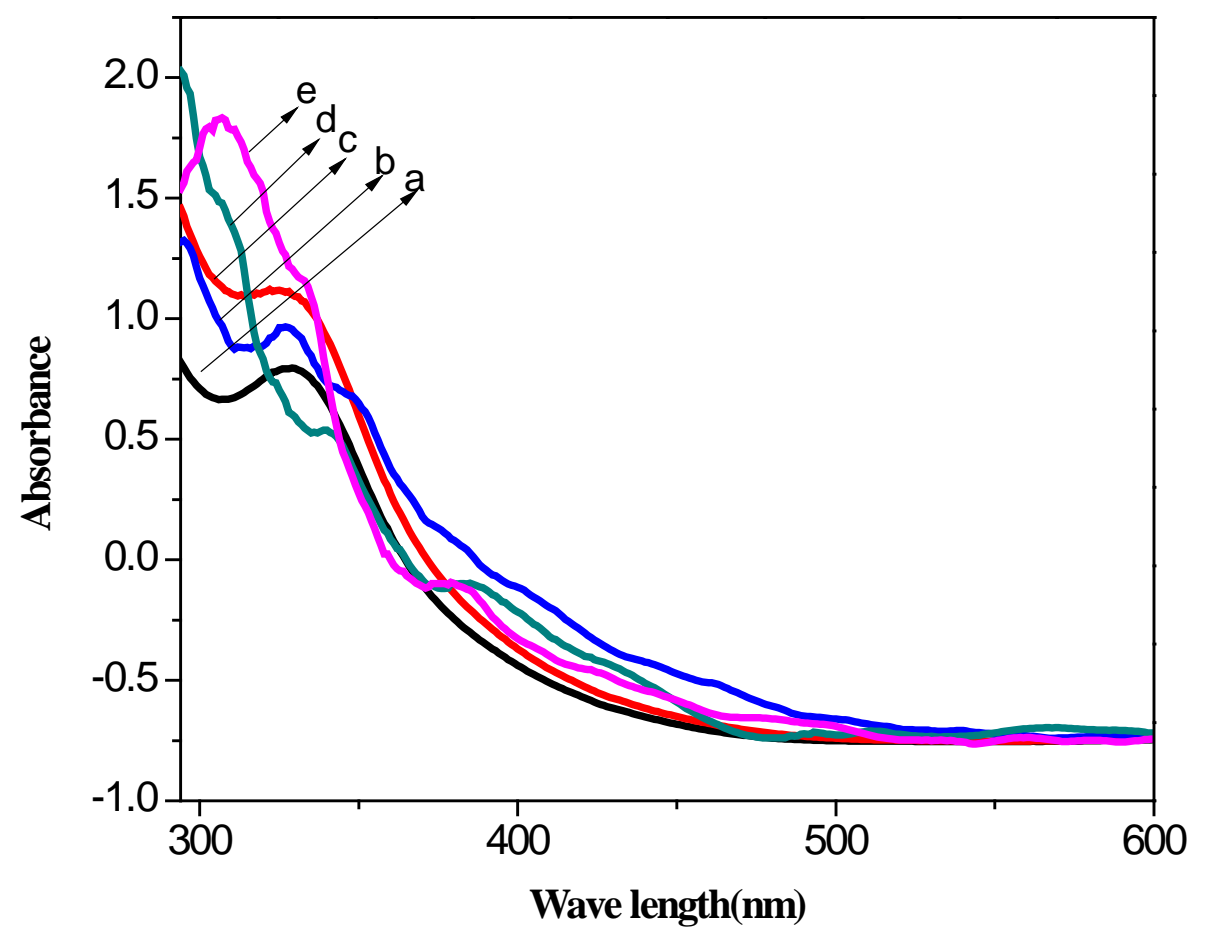

Fig. 6 The UV-Vis spectra of CuO NPs formed using $2 \mathrm{~mL}$ of $2 \%(\mathrm{~m} / \mathrm{v})$ leaf extract of Khat and $45 \mathrm{~mL}$ of (a) $1 \mathrm{mM}$, (b) $2 \mathrm{mM}$, (c) $3 \mathrm{mM}$, (d) $4 \mathrm{mM}$ and (e) $5 \mathrm{mM} \mathrm{CuSO} \cdot 5 \mathrm{H}_{2} \mathrm{O}$ at $\mathrm{pH}=10$.

peaks were full of noises. This reveals that the Khat extract has dominated the solution and the nanoparticles formed have become more unstable. The increase in sharpness indicates that the size of the nanoparticle decreases more as the concentration of the Khat extract is increased which agrees with the concept that; progressive increase in the characteristic peak with increase in concentration of biological extracts with the same amount of salt ions is a clear indicator of nanoparticles formation [39]. Considering all these facts, extract of $2 \%(\mathrm{~m} / \mathrm{v})$ Khat was taken as the best concentration of the extract for its smooth peak with good intensity. It was noticed that increasing the concentration above $2 \%(\mathrm{~m} / \mathrm{v})$ formed peaks with noise. Therefore, increasing the concentration above this value might ultimately make the nanoparticles unstable [5].

3.4.3 Optimization of $\mathrm{pH}$ of the Mixture of Khat Extract and the Precursor

Other parameter to be optimized was the $\mathrm{pH}$ of the $\mathrm{CuO}$ NPs solution. The $\mathrm{pH}$ values of the precursor, the extract, and the nanoparticles before $\mathrm{pH}$ was adjusted were 5.4, 5.5 and 4.15, respectively. The CuO NPs synthesized at different $\mathrm{pH}$ values $(6,7,8,9.5,10,11$, 12 , and 13 ) were optimized based on intensity of their peak and red shift of their respective $\lambda_{\max }$ values. The best result for synthesis of CuO NPs was obtained at $\mathrm{pH}=11$ in Fig 8. This shows that a more basic media is very suitable for the $\mathrm{CuO}$ NPs synthesis [16]. The plasmon resonance was clearly stronger for $\mathrm{pH} 9$ to 12 . At $\mathrm{pH}=12$, the peak was still strong but of course weaker when compared to $\mathrm{pH}=11$.

The maximum blue shift in surface plasmon resonance peak around the maximum value at $\mathrm{pH}=11$ could be attributing to the decrease in the particle size. The added $\mathrm{NaOH}$ solution is expected to act as a catalyst for the formation of the nanoparticle by making particles to collide and connect to each other so as to form homodispersed nanoparticles [19]. But increasing the $\mathrm{pH}$ above 12 might hinder the formation of the $\mathrm{CuO}$ NPs. This is expected to happen when the added $\mathrm{NaOH}$ solution does react directly with the copper 


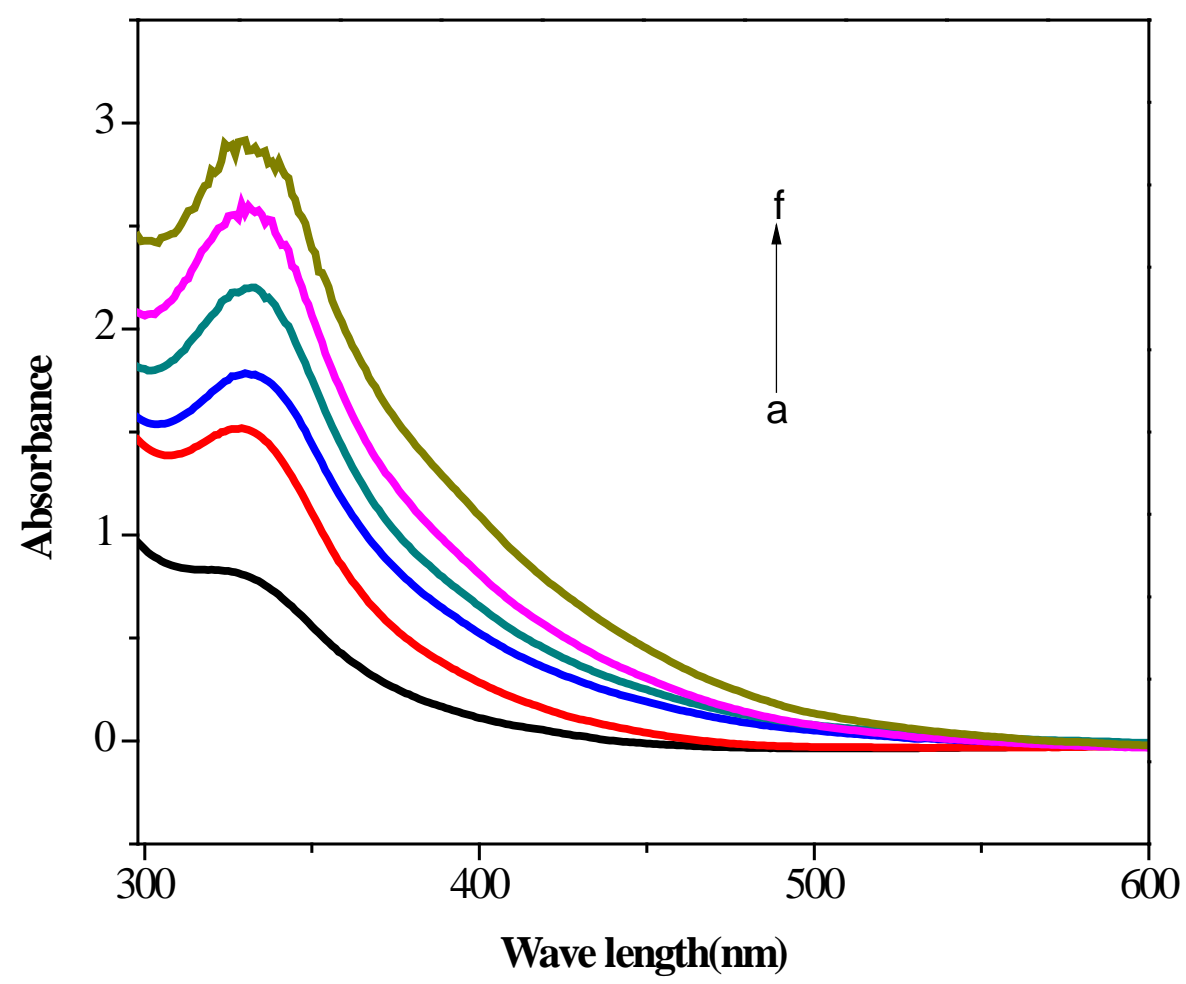

Fig. 7 The UV-Vis spectra of CuO NPs formed using $45 \mathrm{~mL}$ of $1 \mathrm{mM} \mathrm{CuSO} \cdot 5 \mathrm{H}_{2} \mathrm{O}$ and (a) $1 \%$, (b) $2 \%$, (c) $3 \%$, (d) $4 \%$, (e) $5 \%$ and (f) $6 \%(\mathrm{~m} / \mathrm{v})$ leaf extract of Khat at $\mathrm{pH}=10$.

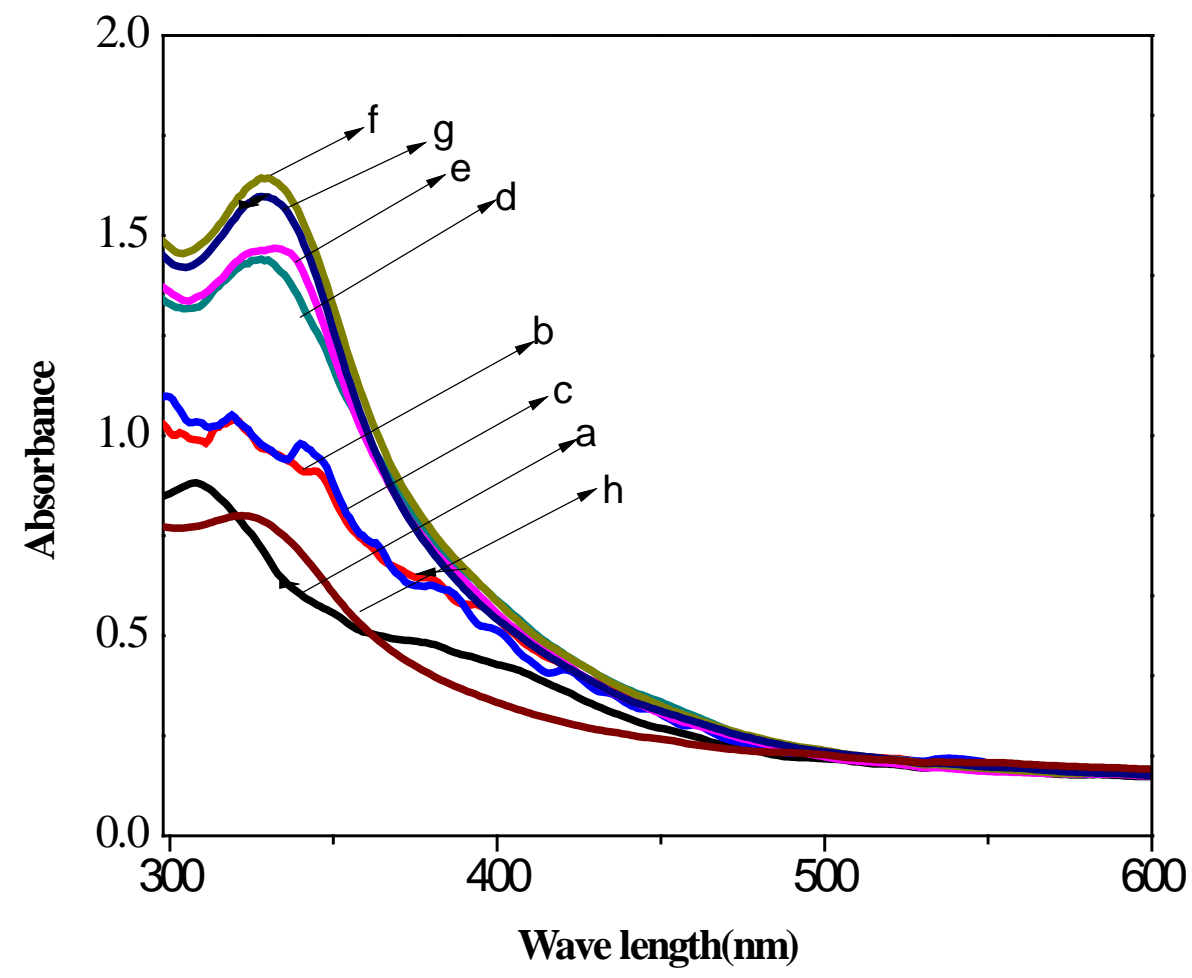

Fig. 8 The UV-Vis spectra of CuO NPs formed using $2 \mathrm{~mL}$ of $2 \%(\mathrm{~m} / \mathrm{v})$ leaf extract of $\mathrm{Khat}$ and $45 \mathrm{~mL} \mathrm{of} 1 \mathrm{mM} \mathrm{CuSO}_{4} \cdot 5 \mathrm{H}_{2} \mathrm{O}$ at pH (a) 6, (b) 7, (c) 8, (d) 9, (e) 10, (f) 11, (g) 12 and (h) 13. 
ions and form $\mathrm{Cu}(\mathrm{OH})_{2}$ with a pale blue color [40].

The stability of the synthesized $\mathrm{CuO}$ NPs was assessed by comparing the UV-Vis spectrum of $\mathrm{CuO}$ NPs at different age. It was then found that the UV-Vis spectrum of the CuO NPs after $24 \mathrm{hr}$ was exactly the same in intensity, broadness and in $\lambda_{\max }$ value with the spectrum $1 \mathrm{hr}$ after synthesis. Even after six days no visible change was observed in the peak intensity and $\lambda_{\max }$ value of the nanopartciles as can be observed in Fig. 9. However, there was of course small increase in intensity of the absorbance and broadness. This is expected to be the result of small increase in size of the particles and rate of aggregation due to the increase in nucleation and coagulation of the nanoparticles formed [16].

\subsection{FT-IR Analysis}

The dual role of the plant extract, as a reducing as well as capping agent, and presence of some functional groups in both the Khat extract and $\mathrm{CuO}$ NPs were investigated by FT-IR analysis [41]. FT-IR analysis was used to identify and get an approximate idea of the possible bio-molecules that are responsible for capping and stabilization of the $\mathrm{CuO}$ NPs with the leaf extract of Khat [26].

A strong peak at $3,416 \mathrm{~cm}^{-1}$ can be attributed due to hydrogen bonded O-H groups of alcohols and phenols and also due to the presence of amines $\mathrm{N}-\mathrm{H}$ of amide. This agrees with the conclusion that leaf extract of Khat is composed of polyphenols, flavonoids, alkaloids and other similar phytochemicals containing O-H and $\mathrm{N}-\mathrm{H}$ bonds, which was confirmed by using qualitative phytochemical analysis. However, this peak shifted to higher field at $3,459 \mathrm{~cm}^{-1}$ in the synthesized CuO NPs, as can be seen in Fig. 10. The shoulder peak at 1,626 $\mathrm{cm}^{-1}$ in leaf extract of Khat could be attributed due to $\mathrm{C}=\mathrm{C}$ stretching, vibrations about $\mathrm{C}=\mathrm{O}$ amide, and conjugated $\mathrm{C}=\mathrm{O}$ of the proteins that are responsible for capping and stabilizing of $\mathrm{CuO}$ NPs. The peaks observed in the range of $646 \mathrm{~cm}^{-1}$ have been assigned to phenolic groups, C-N stretching vibrations of aliphatic and aromatic amines.

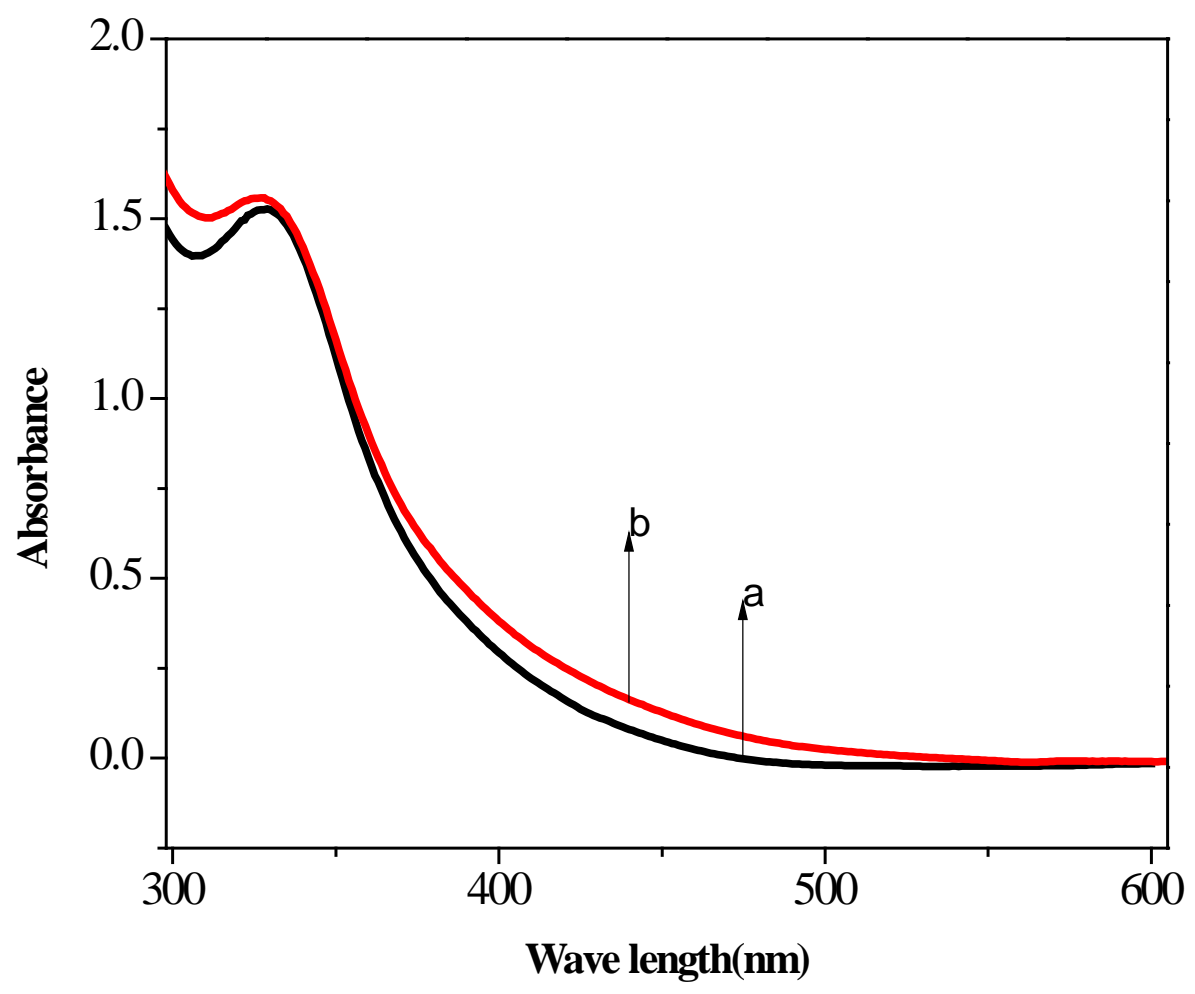

Fig. 9 The UV-Vis spectra of CuO NPs after (a) 1 day and (b) 6 days. 


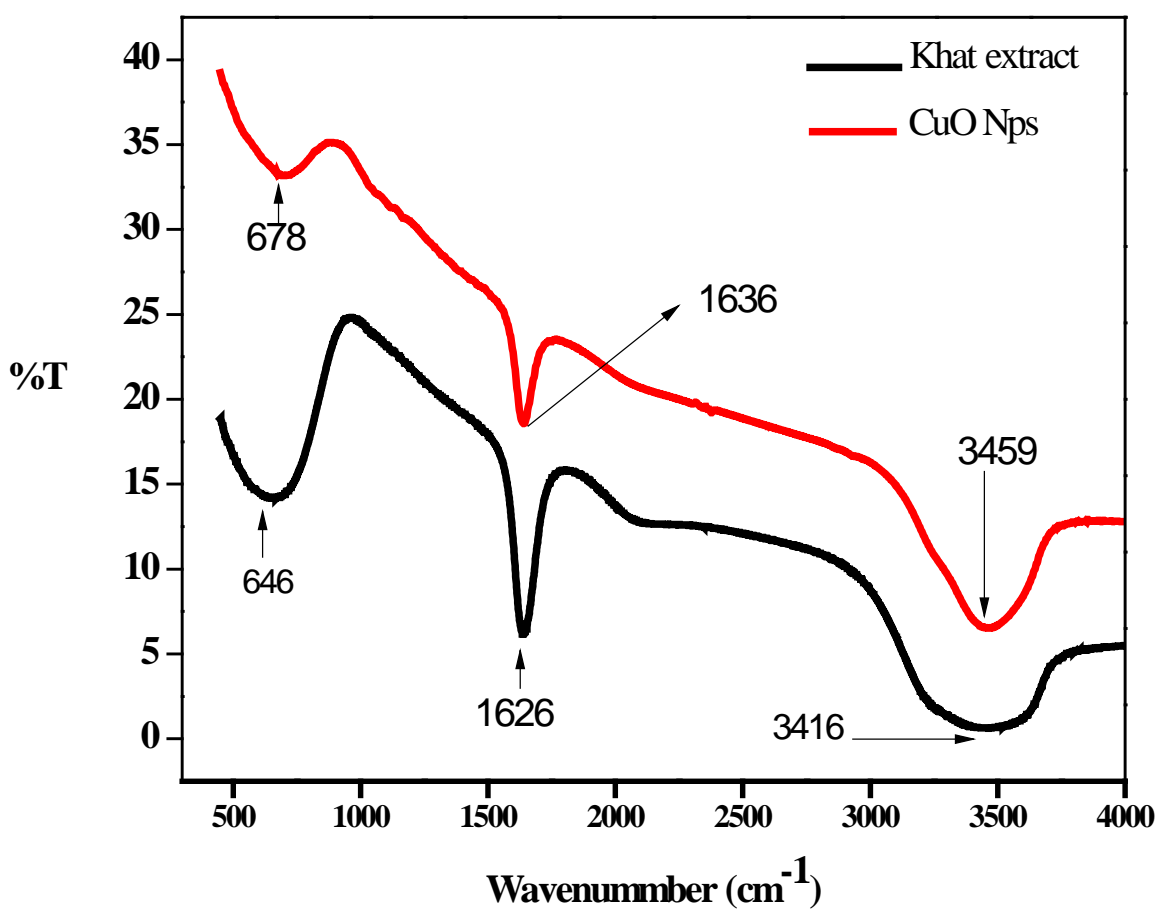

Fig. 10 FT-IR spectra of leaf extract of Khat.

The major peak observed at $678 \mathrm{~cm}^{-1}$ should be a stretching of $\mathrm{Cu}-\mathrm{O}$ which is very closer to the results of some previous works [11]. The bands at $1,626 \mathrm{~cm}^{-1}$ of the leaf extract of Khat shifted to higher field at 1,636 $\mathrm{cm}^{-1}$, in the product (Fig. 10). These bands are assigned to $\mathrm{C}-\mathrm{O}$ stretching, $\mathrm{C}=\mathrm{O}$ stretching and $\mathrm{N}-\mathrm{H}$ bending. The shift in these bands is clearly indicating that the coordination of carboxylic acids in the protein of leaf extract of Khat with CuO NPs plays a major role in dispersing, stabilizing and capping of CuO NPs [7, 26].

\subsection{Antibacterial Activity of $\mathrm{CuO}$ NPs}

The antimicrobial property of CuO NPs was investigated using Salmonella typhimurium and Escherichia coli bacterium species. The bactericidal effect of CuO NPs was studied based on diameter of inhibition zone in disk diffusion tests of nanoparticles dispersed in batch cultures. As can be observed in Table 1, the CuO NPs showed good antibacterial activity against Salmonella typhimurium, with a maximum inhibition zone of $14 \mathrm{~mm}$. But for the Escherichia coli, the CuO NPs have shown relatively lower zone of inhibition i.e., $10 \mathrm{~mm}$ after $24 \mathrm{hr}$ incubation with two trials which agree with results obtained so far [7, 26].

The results revealed that the bacterial sensitivity to nanoparticles was found to vary depending on the microbial species. It was also possible to observe from Fig. 11 that the $\mathrm{CuO}$ NPs were more sensitive to the bacterial as compared to the Khat extract and the precursor $\mathrm{CuSO}_{4} \cdot 5 \mathrm{H}_{2} \mathrm{O}$.

According to different researchers, the exact mechanism of the antimicrobial activity of CuO NPs is not well known and needs to be further studied. But there are many hypothesiszed ways of explaining it. Nanoparticles attached to the microbial surfaces can decrease both cell mobility and nutrient flow between the cell's exterior and interior compartments [42].

Based on previous studies, the denaturing effect of copper ion on proteins and enzymes in microbes gives $\mathrm{CuO}$ NPs its antimicrobial characteristics. The mechanism of toxicity of CuO NPs in the cellular membrane was also suggested to follow a Trojan horse-type mechanism (Fig. 12). If these nanoparticles are soluble they can penetrate the membrane cancelling the barrier function of the membrane. After entering 
Table 1 In vitro antimicrobial activity of CuO NPs using some human pathogenic bacteria by disc diffusion assay.

\begin{tabular}{llll}
\hline S. No. & Test organism & No. of trials & Zone of inhibition (mm) \\
\hline \multirow{2}{*}{1} & \multirow{2}{*}{ Salmonella typhimurium } & 1 & 11 \\
& & 2 & 14 \\
\hline \multirow{2}{*}{ Escherichia coli } & 1 & 10 \\
& & 2 & 6 \\
\hline
\end{tabular}
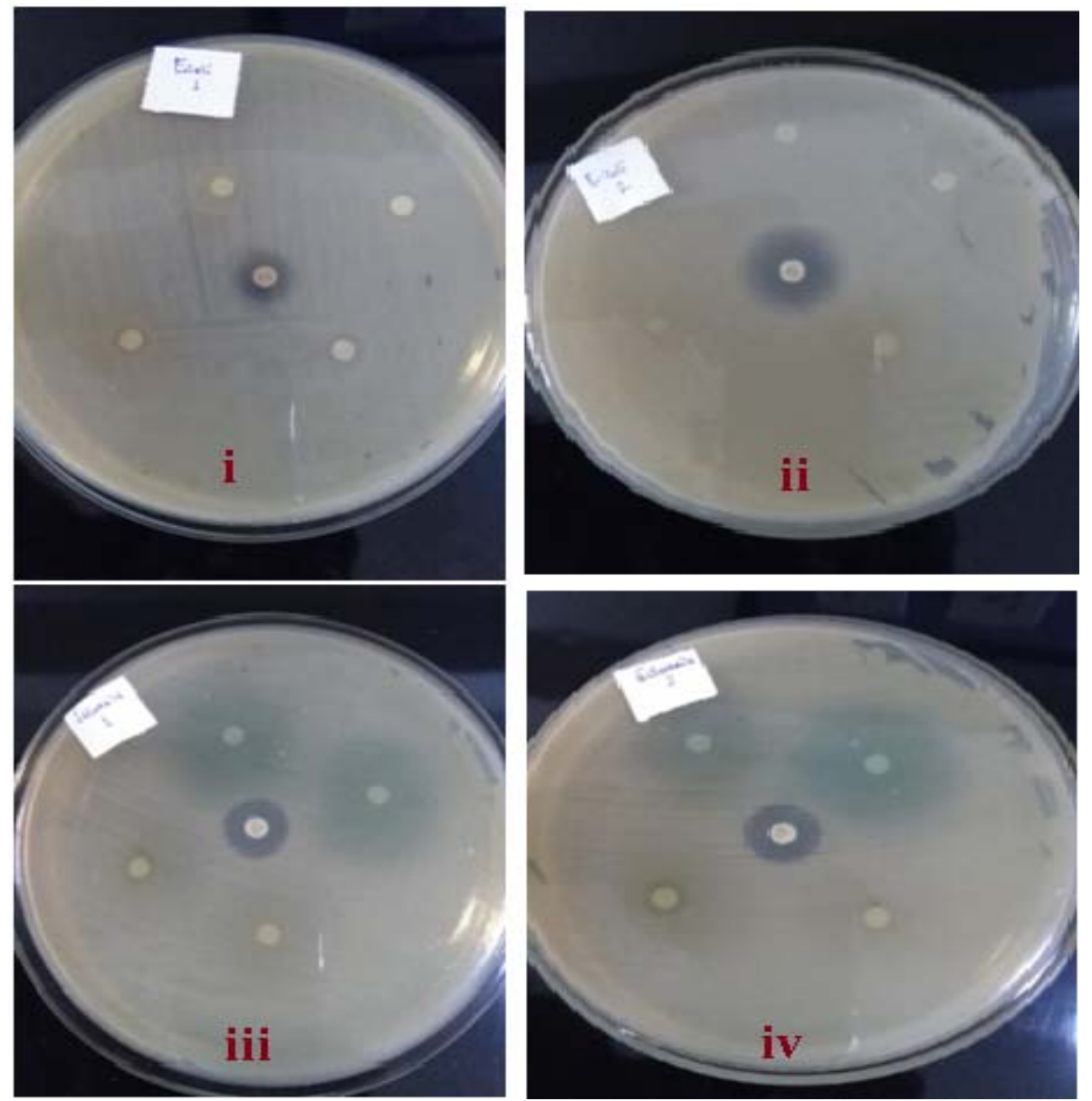

Fig. 11 Zone of inhibition produced by CuO NPs against Escherichia coli (i and ii) and Salmonella typhimurium (iii and iv). 


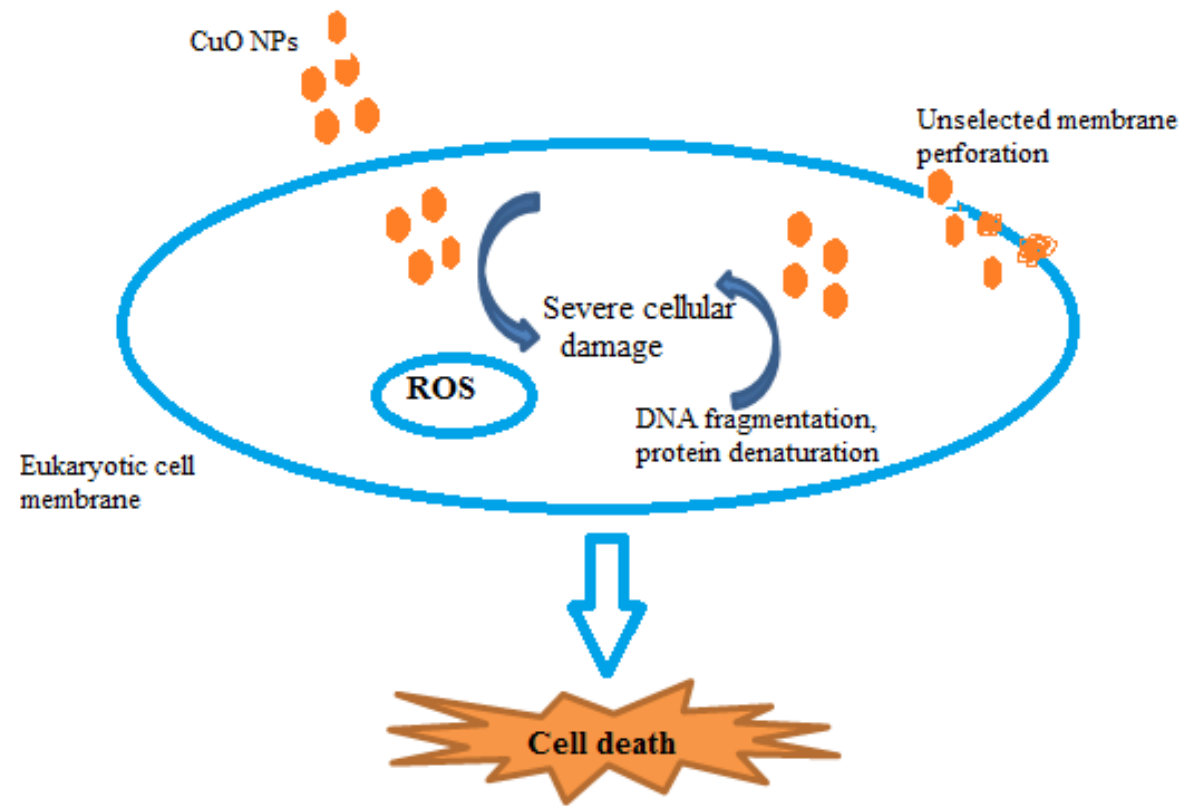

Fig. 12 Mechanism of toxicity of CuO NPs in eukaryotic cell.

the cells, nanoparticles are able to dissolve at acidic intracellular $\mathrm{pH}=4.5$ and metal ions produce pores in the membrane [43].

\section{Conclusions}

The green chemistry approach used in the present work for the synthesis of $\mathrm{CuO}$ NPs using leaf extract of Khat as reducing, capping and stabilizing agent was simple, cost effective and the resultant nanoparticles are highly stable and reproducible. Khat is one of the plants composed of many phytochemicals and is used to synthesize $\mathrm{CuO}$ NPs. The synthesized CuO NPs have been found to have maximum absorbance at a wavelength of $333 \mathrm{~nm}$ which is very much different from the $294 \mathrm{~nm}$ of the Khat extract. The UV-Vis absorption spectrum indicates red shift with increasing concentration of the plant extract to a certain value (2\% $(\mathrm{m} / \mathrm{v}))$ and decreasing the precursor concentration (1 $\mathrm{mM} \mathrm{CuSO} \cdot 5 \mathrm{H}_{2} \mathrm{O}$ ) in the reaction mixture during the synthesis. The FT-IR for $\mathrm{CuO}$ NPs showed that there was newly formed peak that is different from the spectrum of the pure leaf extract of Khat. The strong peak at $678 \mathrm{~cm}^{-1}$, which was not found in the pure leaf extract of Khat, was considered to be the major indicator for the formation of the CuO NPs. Therefore, it is possible to synthesize $\mathrm{CuO}$ NPs using $\mathrm{CuSO}_{4} \cdot 5 \mathrm{H}_{2} \mathrm{O}$ as a precursor and leaf extract of Khat as a reducing agent. $\mathrm{CuO}$ NPs prepared from above route do have appreciable application in killing bacteria. It was found that the CuO NPs have an average inhibition zone of $12.5 \mathrm{~mm}$ and $8 \mathrm{~mm}$ for Salmonella typhimurium and Escherichia coli, respectively.

\section{Acknowledgements}

We thank Bahir Dar University, College of Science for giving us the permission to use the laboratory chemicals, materials and instruments necessary for this work. We are also grateful to the College of Material Science and Engineering of Bahir Dar University for letting us use the UV-Vis spectrometer. We would like to thank the staff members of Chemistry Department of Bahir Dar Uiversity; Dr. Alemu Tesfaye, Dr. Mearge Amare, Dr. Thtina Asmelash, Dr. Minaleshewa Atlabachew and Dr. Atakilt Abebe, for their all-rounded support.

\section{Funding}

This research did not receive specific funding. It was performed as part of the author's M.Sc. thesis work submitted to Bahir Dar University, Ethiopia in 
2017.

\section{Conflict of Interest}

The authors declare no conflict of interest.

\section{References}

[1] Arivalagan, K., Ravichandran, S., Rangasamy, K., and Karthikeyan, E. 2011. "Nanomaterials and Its Potential Applications." International Journal of Chem Tech Research 3 (2): 534-8.

[2] Daniel, M. C., and Astruc, D. 2004. "Gold Nanoparticles: Assembly, Supramolecular Chemistry, Quantum-Size-Related Properties, and Applications toward Biology, Catalysis, and Nanotechnology.” Chemical Revision 104 (1): 293-346.

[3] Banerjee, P., Satapathy, M., Mukhopahayay, A., and Das, P. 2014. "Leaf Extract Mediated Green Synthesis of Silver Nanoparticles from Widely Available Indian Plants: Synthesis, Characterization, Antimicrobial Property and Toxicity Analysis.” Bioresources and Bioprocessing 1 (3): 2-10.

[4] Sylvia Devi, H., and Singh, T. D. 2014. "Synthesis of Copper Oxide Nanoparticles by Anovel Method and Its Application in the Degradation of Methyl Orange.” Advance inElectronic and Electric Engineering 4 (1): 83-8.

[5] Jayalakshmi, A. Y. 2014. "Green Synthesis of Copper Oxidenanoparticles Using Aqueous Extract of Flowers of Cassia alata and Particles Characterization.” International Journal of Nanomaterials and Biostructures 4 (4): 66-71.

[6] Ahamed, M., Alhadlaq, H. A., Khan, M. A. M., Karuppiah, P., and Al-Dhabi, N. A. 2014. "Synthesis, Characterization, and Antimicrobial Activity of Copper Oxide Nanoparticles.” Hindawi Publishing Corporation, Journal of Nanomaterials, 1-5.

[7] Srivastava, S., Kumar, M., Agrawa, A., and Dwivedi, S. K. 2013. "Synthesis and Characterization of Copper Oxide Nanoparticles." IOSR Journal of Applied Physics (IOSR-JAP) 5 (4): 61-5.

[8] Zhang, D. E., Zheng, H. G., Zhang, X. J., and Song, J. M. 2006. "Fabrication of Rod-Like $\mathrm{CeO}_{2}$ : Characterization, Optical and Electrochemical Properties.” Solid State Sciences 8 (11): 1290-3.

[9] Ren, G., Hu, D., Cheng, E. W. C., Vargas-Reus, M. A., Reip, P., and Allaker, R. P. 2009. "Characterization of Copper Oxide Nanoparticles for Antimicrobial Applications." International Journal of Antimicrobial Agents 33 (6): 587-90.

[10] Anantharaman, A., George, L., and George, M. 2016. "Green Synthesis of Copper Oxide Nanoparticles and Its Applications.” International Journal of Advance Research in Science \& Engineering 5 (9): 522.

[11] Sutradhar, P., Saha, M., and Maiti, D. 2014. "Microwave Synthesis of Copper Oxide Nanoparticles Using Tea Leaf and Coffee Powder Extracts and Its Antibacterial Activity." Journal of Nanostructure Chemistry 4 (86): 2-6.

[12] Dur'an, N., Marcato, P. D., Dur'an, M., Yadav, A., Gade, A., and Rai, M. 2011. "Mechanistic Aspects in the Biogenic Synthesis of Extracellular Metal Nanoparticles by Peptides, Bacteria, Fungi, and Plants.” Applied Microbiology and Biotechnology 90 (5): 1609-24.

[13] Rubilar, O., Rai, M., Tortella, G., Diez, M. C., Seabra, A. B., and Dur'an, N. 2013. "Biogenic Nanoparticles: Copper, Copper Oxides, Copper Sulphides, Complex Copper Nanostructures and Their Applications.” Biotechnology Letters 35 (9): 1365-75.

[14] Mallick, P., and Sahu, S. 2012. "Structure, Microstructure and Optical Absorption Analysis of $\mathrm{CuO}$ Nanoparticles Synthesized by Sol-Gel Route.” Nanoscience and Nanotechnology 2 (3): 71-4.

[15] Rahnama, A., and Gharagozlou, M. 2012. "Preparation and Properties of Semiconductor CuO Nanoparticles via a Simple Precipitation Method at Different Reaction Temperatures.” Opt Quant Electron 44: 313-22.

[16] Caroling, G., Vinodhini, E., Mercy Ranjitham, A., and Shanthi, P. 2015. "Biosynthesis of Copper Nanoparticles Using Aqueous Phyllanthus embilica (Gooseberry) Extract-Characterization and Study of Antimicrobial Effects." International Journal of Nanomaterials and Chemistry 1 (2): 53-63.

[17] Bhuvana, N., and Vanitha, S. 2016. "Green Synthesis of Copper, Silver and Iron Nanoparticles: A Review.” IOSR Journal of Applied Chemistry (IOSR-JAC) 9 (6): 49-53.

[18] Ahmada, A., Mukherjeeb, P., Senapatib, S., Mandalb, D., Khanb, M. I., Kumarb, R. M. 2003. "Extracellular Biosynthesis of Silver Nanoparticles Using the Fungus Fusarium oxysporum." Colloids and Surfaces B: Biointerfaces 28 (4): 313-8.

[19] Suresh, Y., Annapurna, S., Bhikshamaiah, G., and Singh, A. K. 2014. "Copper Nanoparticles, Green Synthesis and Characterization.” International Journal of Scientific \& Engineering Research 5 (3): 156-60.

[20] Suresh, Y., Annapurna, S., Singh, A. K., and Bhikshamaiah, G. 2014. "Green Synthesis and Characterization of Tea Decoction Stabilized Copper Nanoparticles." International Journal of Innovative Research in Science, Engineering and Technology 3 (4): 11265-70.

[21] Hasan, S., and Singh, S. 2008. "Bacterial Synthesis of Copper/Copper Oxide Nanoparticles.” Journal of Nanoscience and Nanotechnology 8 (6): 3191-6.

[22] Sivaraj, R., Pattanathu Rahman, K. S. M., Rajiv., P., Narendhran, S., and Venckatesh, R. 2014. "Biosynthesis 
and Characterization of Acalypha indica Mediated Copper Oxide Nanoparticles and Evaluation of Its Antimicrobial and Anticancer Activity.” Molecular and Biomolecular Spectroscopy 129: 255-8.

[23] Acharyulu, N. P. S., Dubey, R. S., Swaminadham, V., Kalyani Pratap Kollu, R. L., and Pammi, S. V. N. 2014. "Green Synthesis of $\mathrm{CuO}$ Nanoparticles Using Phyllanthus amarus Leaf Extract and Their Antibacterial Activity against Multidrug Resistance Bacteria.” International Journal of Engineering Research \& Technology (IJERT) 3 (4).

[24] Yallappa, S., Manjanna, J., Sindhe, M. A., Satyanarayan, N. D., Pramod, S. N., and Nagaraja, K. 2013. "Microwave Assisted Rapid Synthesis and Biological Evaluation of Stable Copper Nanoparticles Using Tarjuna bark Extract.” Spectrochimica Acta Part A: Molecular and Biomolecular Spectroscopy 110: 108-15.

[25] Sharma, J. K., Shaheer Akhtar, M., Ameen, S., Srivastava, P., and Singh, G. 2015. "Greensynthesis of $\mathrm{CuO}$ Nanoparticles with Leaf Extract of Calotropis gigantea and Its Dye Sensitized Solar Cells Applications.” Journal of Alloys and Compounds 632: 321-5.

[26] Awwad, A. M., Albiss, B. A., and Salem, N. M. 2015. "Antibacterial Activity of Synthesized Copper Oxide Nanoparticles Using Malva sylvestris Leaf Extract.” SMUMedical Journal 2 (1).

[27] Jayalakshmi, A. Y. 2014. “Green Synthesis of Copper Oxide Nanoparticles Using Aqueous Extract of Flowers of Cassia alata and Particles Characterization.” International Journal of Nanomaterials and Biostructures 4 (4): 66-71.

[28] Naika, H. R., Lingaraju, K., Manjunath, K., Kumar, D., Nagaraju, G., Suresh, D., and Nagabhushana, H. 2015. "Green Synthesis of CuO Nanoparticles Using Gloriosa superba L. Extract and Their Antibacterial Activity.” Journal of Taibah University for Science 9: 7-12.

[29] Sankar, R., Manikandan, P., Malarvizhi, V., Fathima, T., Shivashangari, K. S., and Ravikumar, V. 2014. "Green Synthesis of Colloidal Copper Oxide Nanoparticles Using Carica papaya and Its Application in Photocatalytic Dye Degradation.” Spectrochimica Acta Part A: Molecular and Biomolecular Spectroscopy 121: 746-50.

[30] Alles, G., Fairchil, M. D., and Jens, M. 1961. "Chemical Pharmacology of Catha edulis.” Journal of Medicinal and Pharmaceutical Chemistry 3 (2).

[31] Al-Motarreb, A., Baker, K., and Broadley, K. 2002. "Khat: Pharmacolgical and Medical Aspects and Its Social Use in
Yemen.” Phytotherapy Research 16: 403-13.

[32] Cox, G., and Rampes, H. 2003. "Adverse Effects of Khat: A Review.” Advanced Psychiatrist Treatment 9: 456-63.

[33] Nencini, P., and Ahmed, A. M. 1989. "Khat Consumption: A Pharmacological Review.” Drug Alcohol Depend 23: 19-29.

[34] Geisshusler, S., and Brenneisen, R. 1987. "The Content of Psychoactive Phenylpropyl and Phenylpentenyl Khatamines in Catha Edulis Forsk of Different origin.” Journal of Ethnopharmacol 19: 269-77.

[35] Ram, S., and Sinha, V. S. 2015. "Qualitative Phytochemical Analyses of Some Plants Use to Cure Malaria in Kolhan Region, of Jharkhand, India.” Journal of Medicinal Plants Studies 3 (6): 60-2.

[36] Gunalan, S., Sivaraj, R., and Rajendran, V. 2012. “Green Synthesized ZnO Nanoparticles against Bacterial and Fungal Pathogens.” Program of Natural Science and Material International 22 (6): 693-700.

[37] Pacheco, B., and Kordyban, S. 2009. "Precise Nanoparticles for Optoelectronics Applications.” Material Matters 7 (1).

[38] Motogoshi, R., Oku, T., Suzuki, A., Kkikchi, K., Kihuchi, S., Jeyadwan, B., and Cuya, J. 2010. "Fabrication and Characterization of Cuprous Oxide Fullerene Solar Cells.” Synthetic Metals 160 (11-12): 1219-22.

[39] Ferrer, N. 2000. "Forensic Science, Applications of IR Spectroscopy." Encyclopedia of Spectroscopy and Spectrometry 1: 603-15.

[40] Maso, R. W., and Jones, S. D. 1990. "Copper and Copper Salts.” G. S. Elliott National Toxicology Group, University of Otago Medical School, Dunedin New Zealand, Accessed at 5 May 2017. http://www.inchem.org/documents/pims/chemical/pimg0 02.htm.

[41] Ahmed, S., Ahmad, M., Swami, B. L., and Ikram, S. 2016. "Green Synthesis of Silver Nanoparticles Using Azadirachta indica Aqueous Leaf Extract." Journal of Radiation Research and Applied Sciences 9: 1-7.

[42] Navarro, E., Baun, A., Behra, R., Hartmann, N. B., Filser, J., and Miao, A. J. 2008. "Environmental Behavior and Eco-Toxicity of Engineered Nanoparticles to Algae, Plants, and Fungi.” Ecotoxicology 17 (5): 372-86.

[43] Subhankari, I., and Nayak, P. L. 2013. "Synthesis of Copper Nanoparticles Using Syzygiumaromaticum (Cloves) Aqueous Extract by Using green Chemistry." World Journal of Nano Science \& Technology 2 (1): 14-7. 